The specimen is a male. It has a wingspread just over 1 inch. On the upperside it is orange on the forewings and dark grey on the hindwings. Both fore- and hind-wings are crossed by a series of white spots. Our specimen is darker on the hindwings than those from much farther south, but it resembles specimens from North and South Dakota.

The Metalmarks resemble the gossamer-winged

butterflies

(Lycaenidae) but the males have forelegs that are not suited for walking and the part of these legs known as the coxae are elongated into spurs. They also have a humeral vein in the hindwing, which is lacking in the lycaenids. Many species have metallic marks in the wings that give them their common name.

Even where metalmarks occur, they are often difficult to find. This may be partly due to the fact that they will sometimes land in the shade on the underside of leaves. Perhaps this is why our specimen was active on a hazy day.

\title{
FIELD GUIDE TO AQUATIC INSECT FAMILIES*
}

\author{
by D. M. LEHMKUHL**
}

Among insects, something like 100 families of a dozen orders which include thousands of species can be found in the streams, rivers, lakes, bogs and springs of North America.

* Reprints are atvailable from the author.

**Dept. of Biology,

University of Saskatchewan.

Saskatoon, Saskatchewan.
Investigations of freshwater habitats by naturalists and students as well as by professional biologists have been hampered by this variety. Keys and guidebooks are too often non-existent, incomprehensible by the nonspecialist, very expensive or out-ofprint. The objective of this pictorial key and field guide is to provide a readily accessible and non-technical introduction to identification of most of the North American families of aquatic insects. 
The practical solution for teaching and survey purposes to the great diversity of insects has been identification to the order and family level. Identification to genus and species has remained the realm of the specialist. This should not be overly discouraging because it is often the family level that we treat as being significant in everyday life and it is this level that often has a common name. For example, mosquitoes are the Family Culicidae and black flies are the Family Simuliidae. Knowing this is probably ample for most people and it takes an above-average enthusiast to care which of the 7 genera and 37 species of mosquitoes is attacking him in Saskatchewan since all the welts look about the same. For those who do care, the necessary publications are listed at the end of this section.

This pictorial key should work for all of North America (with a western bias due to my personal experience). I have avoided technical terms and characters whenever possible. I have also attempted to use characters which can be seen with the naked eye or with a $10 \mathrm{X}$ hand lens; only rarely will a microscope be necessary. Thus, the key should be useful in field as well as laboratory and, hopefully, it can be used by anyone, regardless of background.

Plates and Illustrations. The important identifying features are illustrated diagrammatically in the nine plates of pictorial key. In the following six plates about two-thirds of the families treated in the key are illustrated by photographs. This is adequate for some groups such as the Stoneflies (Plecoptera) where all families basically look alike except for details described in the key. There are other look alikes also. Baetidae and
Metretopodidae (not illustrated) resemble Siphlonuridae (Fig. 10) Ephemeridae resemble Polymitarcidae (Fig. 9). Tricorythidae resemble Caenidae (Fig. 4). Lestidae are similar to Coenagrionidae (Fig. 14). Macroveliidae (Fig. 27) look very much like Veliidae, Mesoveliidae and Hebridae. Nepidae resemble huge Hydrometridae (Fig. 26) and Naucoridae look like small versions of Belostomatidae (Fig. 22). Great variety can be found in the cases of Caddisflies while the larvae are quite uniform, yet differing as indicated in the key. In other groups, such as Mayflies (Ephemeroptera) and Flies (Diptera), so much diversity is found that some types are not illustrated.

Collecting and Preserving. We are concerned here with only the aquatic stages of insects and any aquatic habitat is likely to yield interesting specimens. No possibility should be overlooked because some specialized insect can be found in almost any type of habitat. Collecting in the samc water area at different seasons will produce different kinds of insects and different stages of growth of the same insects.

Useful collecting equipment in cludes rubber boots, a white ename pan or photographic developing tray, pair of forceps, a "turkey baster", notebook, and a net or two as sold by aquarium shops and biological supply houses. Place 1 or 2 inches of wate from the pond or river into the whit pan. Then sweep the net througl vegetation or debris stirred up fron the bottom and put the collecter material into the pan. Rocks held ove the pan can be rinsed off with th baster. A variety of life should b easily visible swimming around agains the white background. Specimens cai now be picked up with forceps o 
baster and transferred to collecting bottles where they can be preserved in alcohol $(80 \%$ ethyl is best, rubbing alcohol will work). All should be labelled with the location and date of collection and the name of the collector. Labels can be written in soft pencil or permanent ink and the label is best placed inside the vial or bottle. If desired, adult beetles (Coleoptera) and bugs (Hempitera) may be pinned.

Aquariums. Aquatic insects represent the full ecological spectrum - herbivores, decomposers, carnivores and even parasites (Hymenoptera, not in key). Thus the possibilities for observing ecological principles in an aquarium, or even keeping a few "pets", should not be overlooked.

Use of the Key. Begin at the top of the page and you will always find two opposing statements connected by a heavy line. Read each statement, decide which is true for your specimen, and then follow the heavy line leading from the true statement. You will then find another pair or triplet of contrasting statements. Again, decide which fits your animal and follow the "true" line. Sooner or later you will reach a name and you will have identified your specimen. Begin with the key to orders and then turn to the key of families for the appropriate order.

Scope of the Key. The key should work for all insects which live in or on water but one may sometimes find land insects which have fallen into the water. Beware of this. Since the objective of this key is primarily to identify the organisms, information on their biology and ecology will have to be obtained from other sources, some of which are at the end of this article. A brief summary of biological information is given in the table.

\section{Possible Problems and Useful Hints.}

Only adult insects have large wings which can be used in flight but sometimes the wings are difficult to recognize because they are modified into hard, shell-like structures (beetles and true bugs). If you are suspicious, try to lift the part in question with a pin. Mature nymphs have small nonfunctional wing buds which cannot be used in flight. Collembola are minute, often black, insects found on the surface of water. Nymphs and larvae: Young grasshoppers are typical insect nymphs while caterpillars and maggots are typical larvae. Forming a mental image of these contrasting types will help you make the proper selection at this step. Non-Insects: with the exception of Diptera larvae, most aquatic insects have six legs. If you find a specimen with more or fewer and if it is not in the key to families of Diptera, you are probably not dealing with an insect. Other keys must be used for non-insects such as the books by Pennak or by Ward and Whipple listed below.

Acknowledgements. I would like to thank John Waddington for taking many of the photographs and preparing the final plates. Drawings and photographs are based on specimens from the author's collection. A long succession of students in university and high school classes have squinted at mimeographed copies of the key as a test of its workability, and to them I am grateful. The editorial staff of the Blue Jay, especially Bernard Gollop and Ed Driver were helpful in every way and made preparation of the manuscript a pleasure. 
GENERAL

BORROR. D. J. and D. M. DeLONG. 1954. An introduction to the study of insects. Holt. Rinehart, and Winston.

BORROR, D. J. and R. E. WHITE. 1970. A field gatide to the insects of America north of Mexico. Houghton Miffin. Boston, 4() 4 p.

PENNAK, R. W. 1953. Freshwater invertehrates of the United States. Ronald Press. New York. $769 \mathrm{p}$.

USINGER, R. L. 1963. Aquatic insects of California with keys to the North American genera and California species. Univ. Calif. Press, 508 p.

WARD, H. B. and G. C. WHIPPLE. 1959. Freshwater Biology. 2nd Ed. W. T. Edmondson (ed.) Wiley, New York. 1248 p.

\section{COLLEMBOLA}

MAYNARD, E. A. 1951. Monograph of the Collembola or Springtail Insects of New York State. Ithaci, N.Y.: Comstock Publ. Co. 339 p.

\section{EPHEMEROPTERA}

BURKS, B. D. 1953. The mayflies or Epherneropteru of Illinois. Bull. Illino is Nat. Hist. Surv. 26: $1-216$.

LEHMKUHL, D. M. 1970. Mayflies in the' Soluth Saskatchewan River; Pollution indicators. Blue Jay. 28: $183-186$.

NEEDHAM, J. G., J. R. TR AVER and Y. HSU. 1935. The biology of inayflies. Ithaca, N.Y. Comstock Publ. Co. 759 p.

\section{ODONATA}

LEHMKUHL. D. M. 1975. Saskatchewan Damselffies and Dragonflies. Blue Jay 33: 18-27.

NEEDHAM, J. G. and M. J. WESTFALL, Jr. 1955. A manual of the dragonflies of North America. Univ. Calif. Press. 615 p.

WALKER, E. M. 1953. The Odonata of Canada and Alaska. The Zygoptera-Darnselflies. Vol. I, Univ. Toronto Press.

1958. The Odonata of Canada and Alaska. The Anisoptera - Four Families. Vol. II, Univ. Toronto Press

WALKER, E. M. and P. S. CORBET, 1975, The Odenata of Canada and Alaska. Libellulidae. Vol. III, Univ. Toronto Press.

\section{PI.FCOPTF.R A}

FRISON, T. H. 1935. The stoneflies, or Plecoptera, of Illinois. Bull. Illinois Nat. Hist. Surv. 20 $281-471$.

HARDEN, P. H. and C. E. MICKEL. 1952. The Stoneflies of Minnesota (Plecoptera). U. of Minnesota. Ag. Expt. Station. Bull. 201. 84 p.

\section{HEMIPTERA}

BROOKS, A. R, and L. A. KELTON, 1967. Aquatic and Semiaquatic Heteroptera of Alberta, Saskatchewan, and Manitoba (Hemiptera). Memoirs. Ent, Soc. Canada No. 51.92 p.

SOUTHWOOD, T. R. E. and D. LESTON, 1959. The land and water hugs of the British Isles, Warne and Co., London and New York. $436 \mathrm{p}$.

\section{MEGALOPTERA}

LEHMKUHL, D. M. 1975. Alcterflies. Blue Jay 33: $152-154$

\section{NEUROPTERA}

PARFIN, S. I. and A. B. GURNEY. 1956. The Spongilla-flies. Proc. U.S. Natl. Museum 105: 421-529. (No. 3360).

\section{TRICHOPTERA}

ROSS, H. H. 1944. The caddis flies, or Trichoptera, of Illinois. Bull. Illinois. Nat. Hist, Surv. 23: 1326.

\section{LEPIDOPTERA}

LANGE, W. H. Jr. 1963. Aquatic Lepidoptera In: Usinger, R. L., Aquatic Insects of California. p. 27I-288. U. of California Press

\section{COLEOPTERA}

HATCH, M. H. 1953. The bectles of the Pacific Northwest. Part I. Introduction and Adephaga. Univ. Washington Publ. Biol. 340 p.

LARSON, D. J. 1975. The Predacesus Water Be'tles (Coleoptera: Dytiscidae) of Alberta: Systematics, Natural History and Distribution. Quaestiones Entomologica 11: 245-498.

\section{DIPTERA}

CARPENTER, S. J. and W. J. LaCASSE 1955 Mosquitoes of North America. U. of California Press. $360 \mathrm{p}$.

COOK, E. F. 1956. The Nearctic Chaoborinae (Diptera: Culcidae). U. of Minnesota Ag. Expt Station. Bull. 218. 102 p.

JOHANNSEN, O. A. 1934-1938. Aquatic Diptera, Parts I-V. Cornell Univ. Ag. Expt. Station (recently reprinted in a single volume).

REMPEL, J. G. 1950. A guide to the inosquito larvae of Western Canada. Can. J. Res, D, 28: 207. 248.

REMPEL, J. G. 1953. The Mosquitoes of Saskatchewan. Can. J. Zool. 31: 433-509.

\section{OTHER}

BOUSQUET, W. S. 1975. Photographing Aquatic Insects. TIEG Newsletter 10: 13-19. (TIEG Editor, 315 Plant Science Bldg., Cornell University, Ithaca, New York. 14853. U.S.A. TIEG stands for Teen International Entomology Group).

DRIVER, E. A. 1974. Insects Invade an Urban Porld. Blue Jay $32: 27-32$.

TONES, Patricia. 1970. Pollation in the North Sastatchewarl River. Blue Jay 28: 111-113. 


\section{KEY TO THE FAMILIES OF}

EPHEMEROPTERA NYMPHS

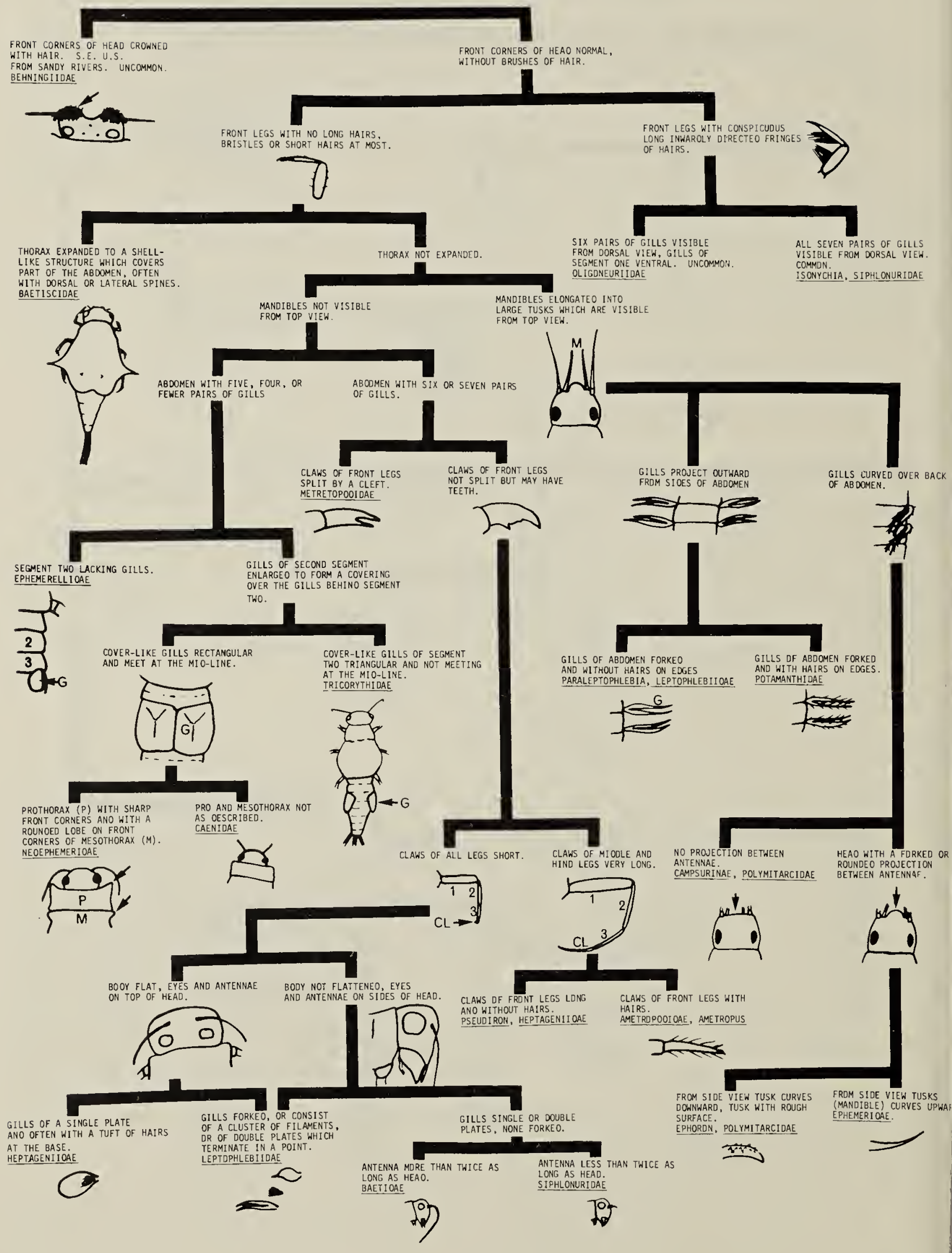



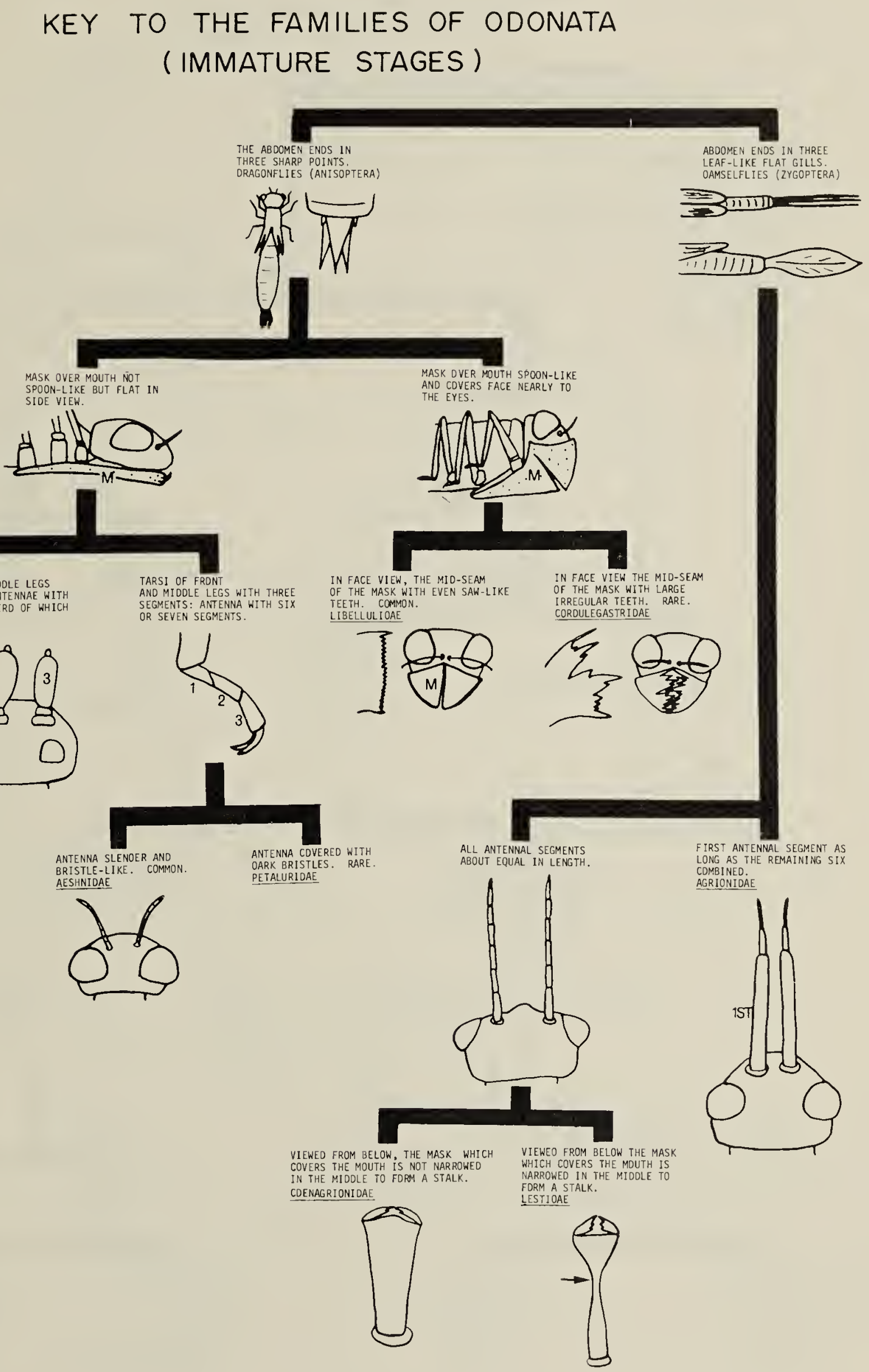


\section{KEY TO THE FAMILIES OF \\ PLECOPTERA NYMPHS}

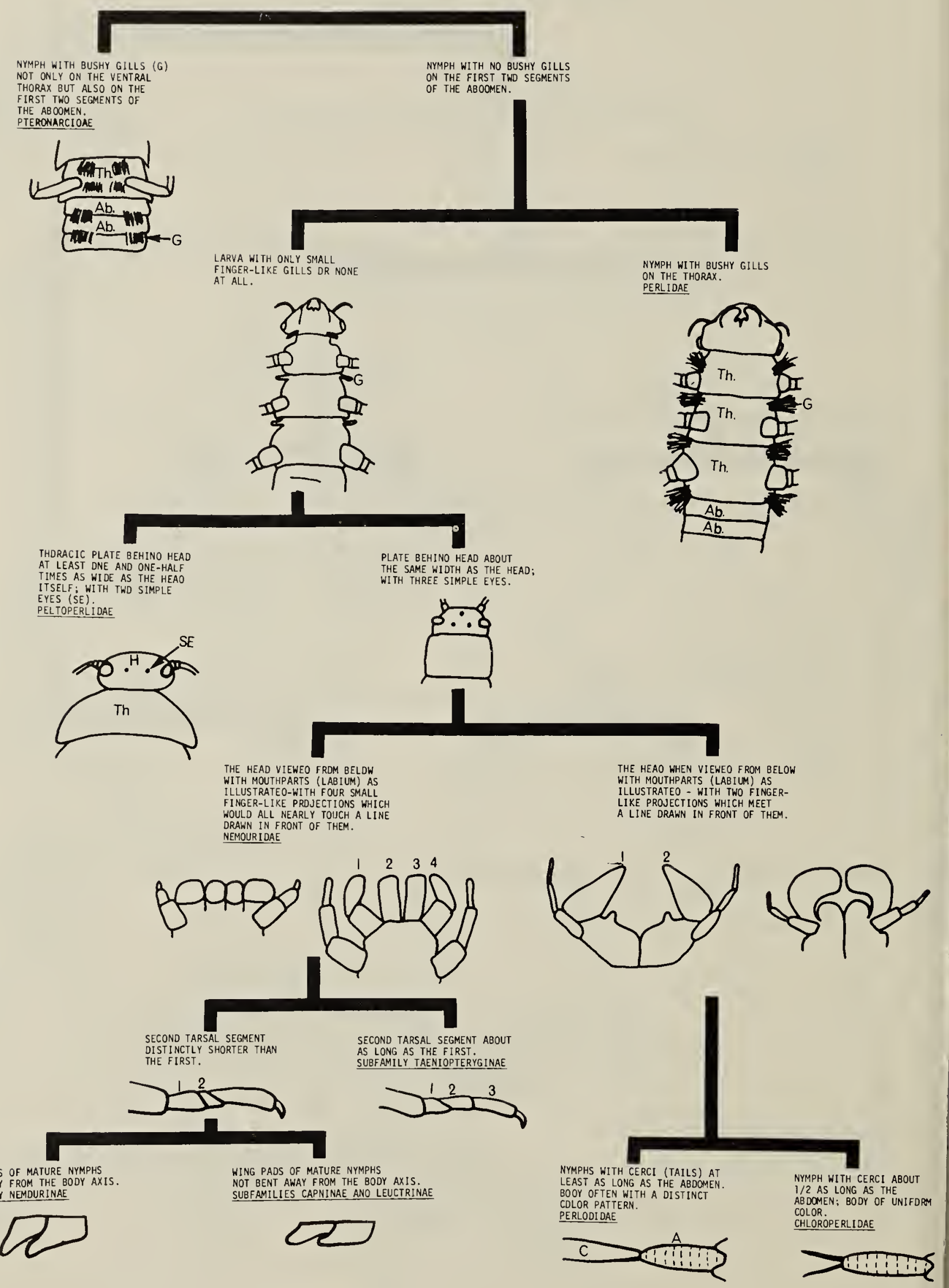




\section{KEY TO THE COMMON FAMILIES OF AQUATIC HEMIPTERA}

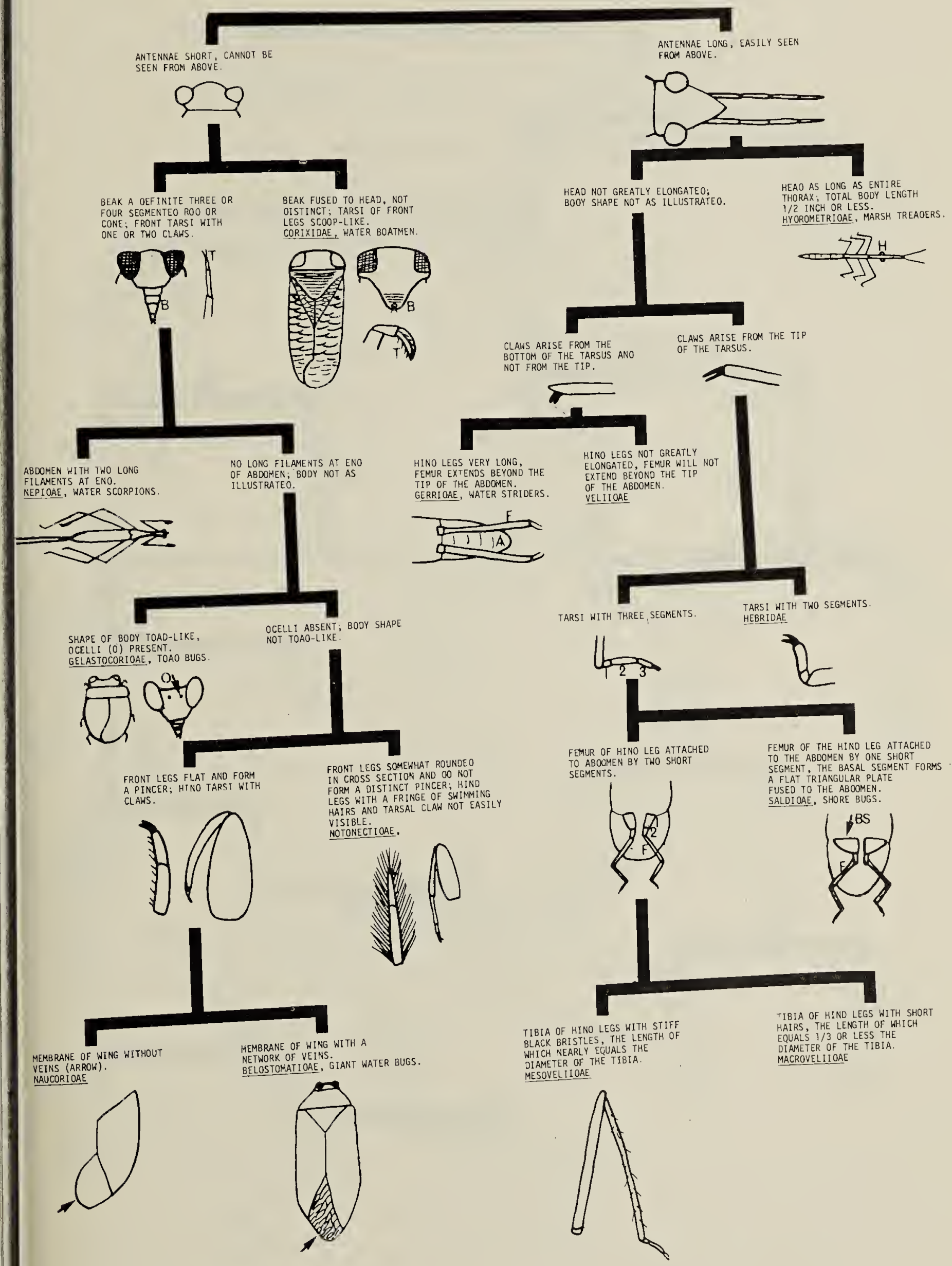




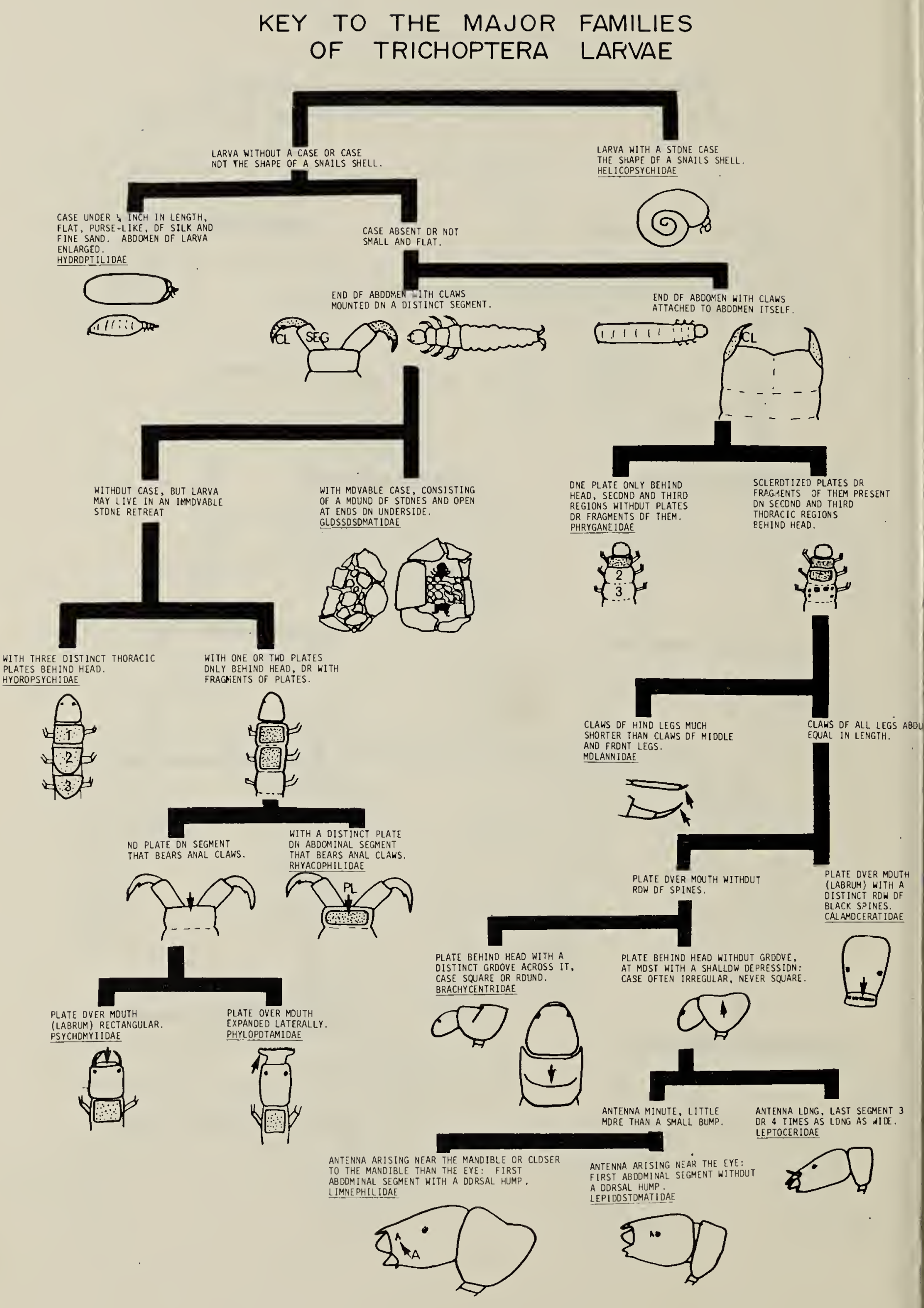




\section{KEY TO THE COMMON FAMILIES OF AQUATIC BEETLES (ADULTS)}

HIND LEGS PROJECTING FROM BENEATH LARGE PLATES WHICH COVER MOST OF THE ABDOMEN. HALIPLIDAE

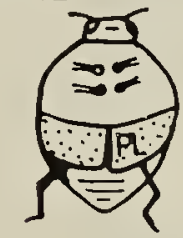

CLAW AND LAST TA SEGMENT NOT AS ILLUSTRATED.

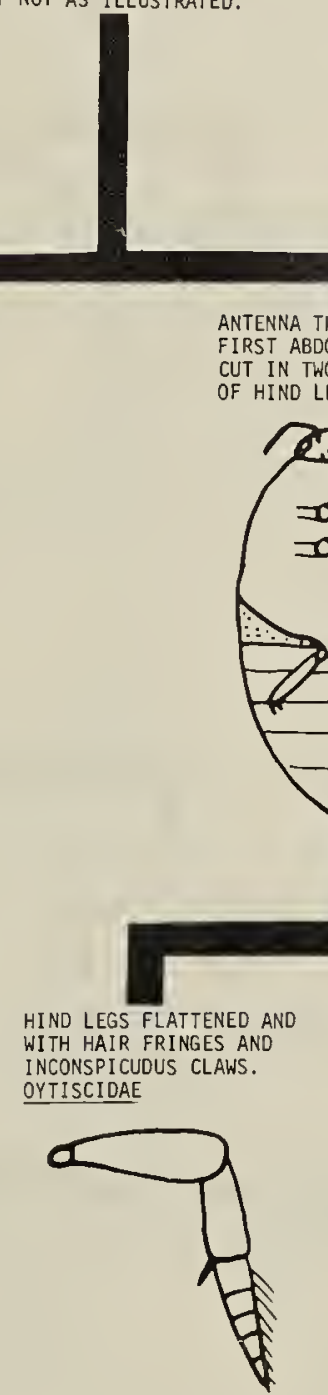

FAD WITH FOUR LARGE ISIBLE ROUND EYES, TWO TWO FROM ABOVE ANO TWO GYRINIOAE

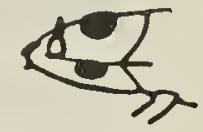

ANTENNA ARISES FROM UNDER

THE EYES AND IS ENLARGED

SEGMENT NOT CUT IN TWO

BY ATTACHMENT OF HIND LEGS.

HYOROPHILIOAE
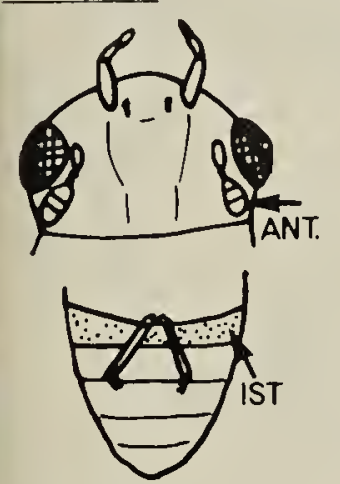

PLATES.
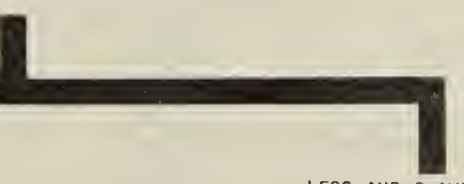

LEGS AND CLAWS LARGE, AS LDNG AS THE BASAL
FOUR SEGMENTS COMBINED

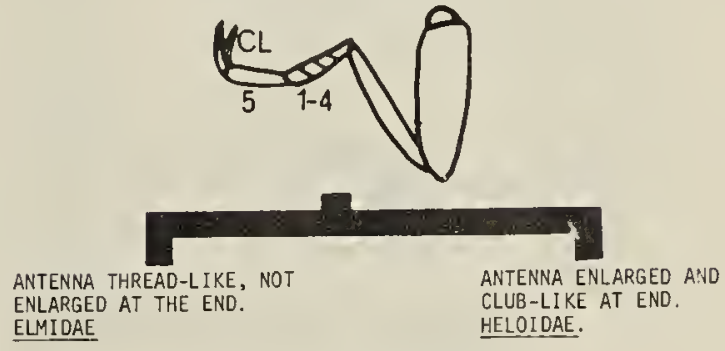
ELMIDAE HELOIDAE.
ANT

0

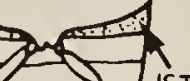

IST 


\section{KEY TO THE COMMON FAMILIES OF AQUATIC BEETLES (LARVAE)}

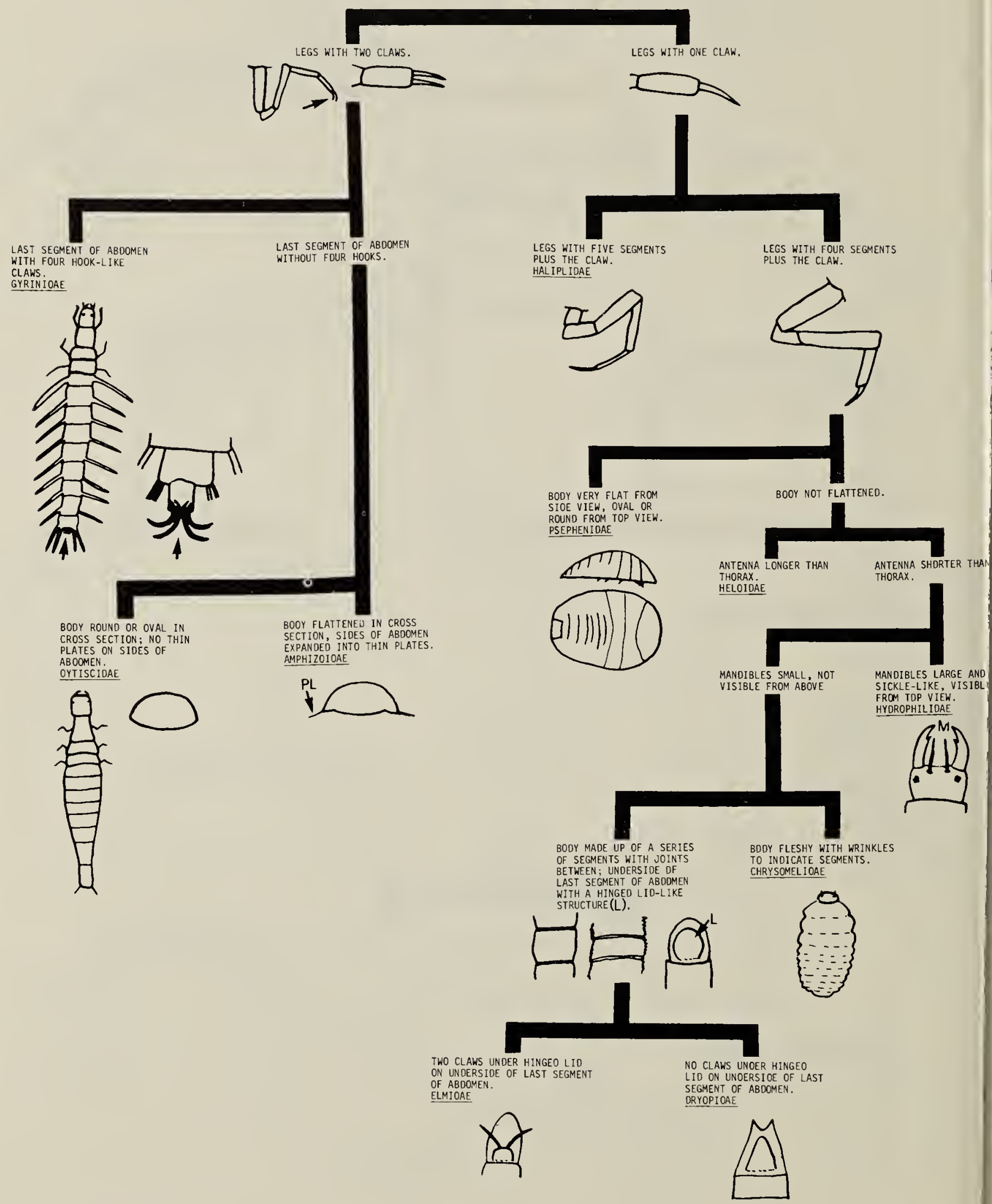


TABLE 1

\section{SOME CHARACTERISTICS OF THE FAMILIES OF NORTH AMERICAN AQUATIC INSECTS}

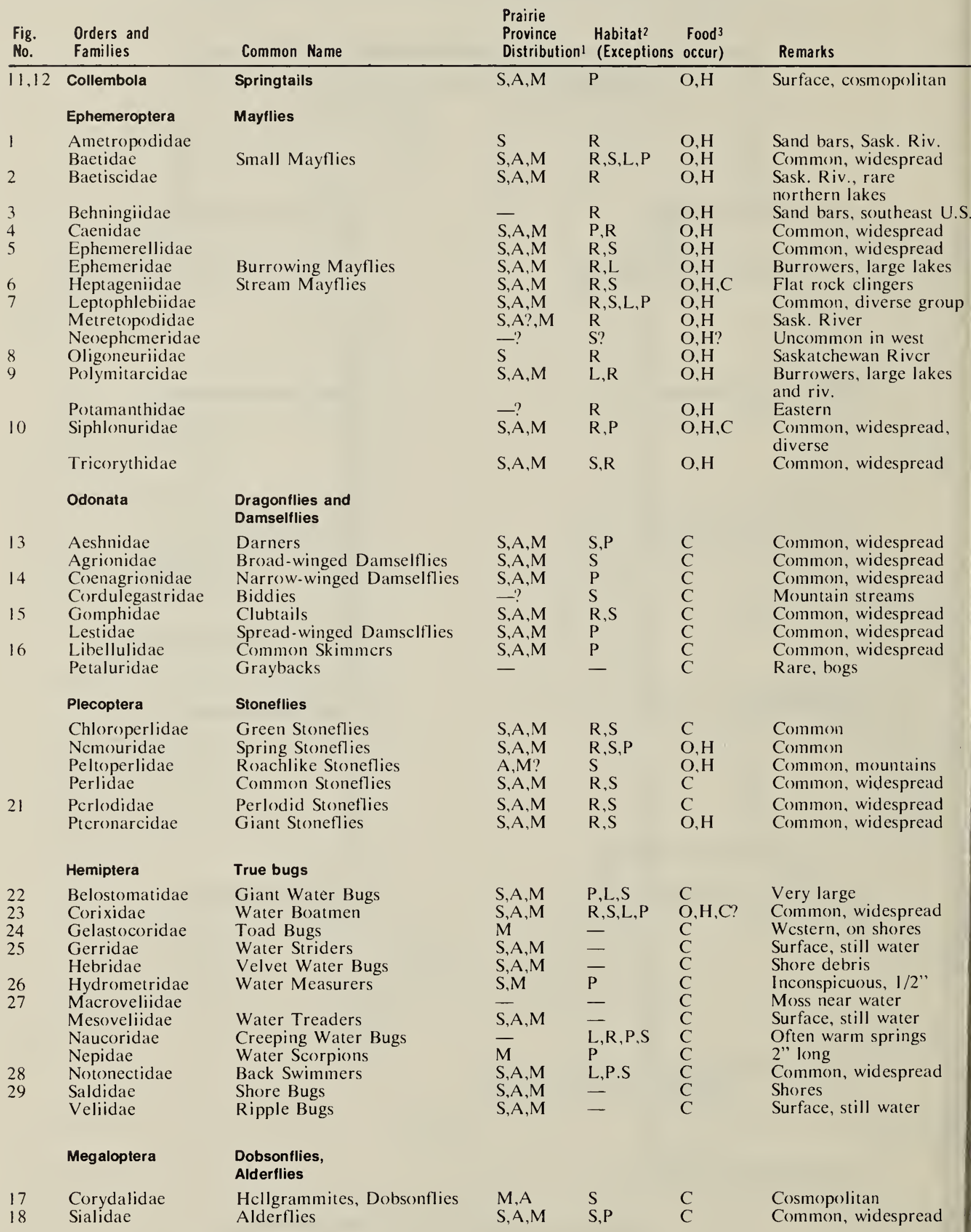


TABLE 1 (Contd.)

SOME CHARACTERISTICS OF THE FAMILIES OF NORTH AMERICAN AQUATIC INSECTS

\begin{tabular}{|c|c|c|c|c|c|c|}
\hline $\begin{array}{l}\text { Fig. } \\
\text { No. }\end{array}$ & $\begin{array}{l}\text { Orders and } \\
\text { Families }\end{array}$ & Common Name & $\begin{array}{l}\text { Prairie } \\
\text { Province } \\
\text { Distribution! }\end{array}$ & $\begin{array}{l}\text { Habitat2 } \\
\text { (Exceptions }\end{array}$ & $\begin{array}{l}\text { Food } 3 \\
\text { occur) }\end{array}$ & Remarks \\
\hline & Neuroptera & Lacewings & & & & \\
\hline \multirow[t]{2}{*}{19} & Sisyridae & Spongillaflies & $\mathrm{S}, \mathrm{A}, \mathrm{M}$ & $\mathrm{P}, \mathrm{S}$ & $\mathrm{C}$ & On freshwater sponges \\
\hline & Trichoptera & Caddisflies & & & & \\
\hline 30 & Brachycentridae & Brachycentrids & $\mathrm{S}, \mathrm{A}, \mathrm{M}$ & $\mathrm{R}, \mathrm{S}$ & $\mathrm{O}, \mathrm{H}$ & Common, widespread \\
\hline \multirow[t]{2}{*}{31} & Calamoceratidae & Calamoceratids & $-?$ & $\mathrm{~S}$ & $\mathrm{O}, \mathrm{H}$ & Uncommon \\
\hline & Glossosomatidae & & $\mathrm{S}, \mathrm{A}, \mathrm{M}$ & $\mathrm{R}, \mathrm{S}$ & $\mathrm{O}, \mathrm{H}$ & Common, widespread \\
\hline 32 & Helicopsychidae & Snail-case Caddisflies & $\mathrm{S}, \mathrm{A}, \mathrm{M}$ & $\mathrm{R}, \mathrm{S}, \mathrm{L}$ & $\mathrm{O}, \mathrm{H}$ & Widespread, warm springs \\
\hline 33 & Hydropsychidae & Net-spinning Caddisflies & $\mathrm{S}, \mathrm{A}, \mathrm{M}$ & $\mathrm{R}, \mathrm{S}$ & $\mathrm{O}, \mathrm{H}$ & Collect food in net \\
\hline \multirow[t]{2}{*}{34} & Hydroptilidae & Micro-caddisflies & $\mathrm{S}, \mathrm{A}, \mathrm{M}$ & $\mathrm{R}, \mathrm{S}$ & $\mathrm{O}, \mathrm{H}$ & Common, seldom collected \\
\hline & Lepidostomatidae & Lepidostomatids & $\mathrm{S}, \mathrm{A}, \mathrm{M}$ & $\mathrm{R}, \mathrm{S}$ & $\mathrm{O}, \mathrm{H}$ & Fairly common \\
\hline 35 & Leptoceridae & Long-horned Caddisflies & $\mathrm{S}, \mathrm{A}, \mathrm{M}$ & $\mathrm{R}, \mathrm{S}, \mathrm{P}, \mathrm{L}$ & $\mathrm{O}, \mathrm{H}, \mathrm{C}$ & Diverse family \\
\hline 36 & Limnephilidae & Northern Caddisflies & $\mathrm{S}, \mathrm{A}, \mathrm{M}$ & $R, S, L, P$ & $\mathrm{O}, \mathrm{H}$ & Common, widespread \\
\hline \multirow[t]{4}{*}{37} & Molannidae & Molannids & $\mathrm{S}, \mathrm{A}, \mathrm{M}$ & L & $\mathrm{O}, \mathrm{H}$ & Common, northern lakes \\
\hline & Philopotamidae & Finger-net Caddisflies & $\mathrm{S}, \mathrm{A}, \mathrm{M}$ & $\mathrm{R}, \mathrm{S}$ & C? & Collect food in net \\
\hline & Phryganiidae & Large Caddisflies & $\mathrm{S}, \mathrm{A}, \mathrm{M}$ & $\mathrm{R}, \mathrm{S}, \mathrm{L}, \mathrm{P}$ & $\mathrm{O}, \mathrm{H}$ & Common, widespread \\
\hline & Psychomyiidae & Tube-making Caddistlies & $\mathrm{S}, \mathrm{A}, \mathrm{M}$ & $\mathrm{R}, \mathrm{S}$ & $\mathrm{O}, \mathrm{H}, \mathrm{C}$ & Collect food in net \\
\hline \multirow[t]{2}{*}{38} & Rhyacophilidae & Primitive Caddisflies & $\mathrm{S}, \mathrm{A}, \mathrm{M}$ & $\mathrm{R}, \mathrm{S}$ & $\mathrm{C}, \mathrm{O}$ & Mountain streams \\
\hline & Lepiodoptera & Moths & & & & \\
\hline \multirow[t]{2}{*}{20} & Pyralidae & Pyralid Moths & $\mathrm{S}, \mathrm{A}, \mathrm{M}$ & $\mathrm{R}, \mathrm{S}, \mathrm{L}$ & $\mathrm{H}$ & $\begin{array}{l}\text { With case on aquatic } \\
\text { plants }\end{array}$ \\
\hline & Coleoplera & Beetles & & & & \\
\hline 39,43 & Amphizoidae & Trout-stream Beetles & A & $\mathrm{S}$ & $\mathrm{C}$ & Rare, mountain streams \\
\hline \multirow[t]{2}{*}{40} & Chrysomelidae & Leaf Beetles & $?$ & $\mathrm{P}, \mathrm{L}$ & $\mathrm{H}$ & Aquatic leafy plants \\
\hline & Dryopidae & Long-toed Water Beetles & $?$ & $\mathrm{~S}$ & $\mathrm{O}, \mathrm{H}$ & Stream bottoms \\
\hline$\overline{4} 1,4 \overline{4}$ & Dytiscidae & Predaceous Diving Beetles & $\mathrm{S}, \mathrm{A}, \mathrm{M}$ & $\mathrm{R}, \mathrm{S}, \mathrm{L}, \mathrm{P}$ & $\mathrm{C}$ & Common, widespread \\
\hline \multirow{4}{*}{42,45} & Elmidae & Riffle Beetles & $\mathrm{S}, \mathrm{A}, \mathrm{M}$ & $S, P$ & $\mathrm{H}$ & Common, widespread \\
\hline & Gyrinidae & Whirligig Beetles & $\mathrm{S}, \mathrm{A}, \mathrm{M}$ & S,L,P & $\mathrm{C}$ & $\begin{array}{l}\text { Common, widespread, } \\
\text { surface }\end{array}$ \\
\hline & Haliplidae & Crawling Water Beetles & $\mathrm{S}, \mathrm{A}, \mathrm{M}$ & $\mathbf{P}$ & $\mathrm{O}$ & Common, widespread \\
\hline & Heloidae & Marsh Beetles & $\mathrm{S}, \mathrm{A}, \mathrm{M}$ & - & $\mathrm{O}$ & Damp areas, moss \\
\hline 46 & Hydrophilidae & Water Scavenger Beetles & $\mathrm{S}, \mathrm{A}, \mathrm{M}$ & $\mathrm{R}, \mathrm{S}, \mathrm{L}, \mathrm{P}$ & $\mathrm{O}, \mathrm{H}$ & Common, widespread \\
\hline \multirow[t]{2}{*}{47} & Psephenidae & Water-penny Beetles & - & $\mathrm{S}$ & $\mathrm{H}$ & Mountain streams \\
\hline & Diptera & Flies & & & & \\
\hline & Anthomyiidae & Anthomyiid Flies & $\mathrm{S}, \mathrm{A}, \mathrm{M}$ ? & $\mathbf{P}$ & $\mathrm{O}, \mathrm{H}$ & Few aquatic species \\
\hline 48 & Blephariceridae & Net-winged Midges & A & $\mathrm{S}$ & $\mathrm{O}, \mathrm{H}$ & Mountain streams \\
\hline 49 & Ceratopogonidae & Biting Midges & $\mathrm{S}, \mathrm{A}, \mathrm{M}$ & $\mathrm{R}, \mathrm{S}, \mathrm{L}, \mathrm{P}$ & $\mathrm{C}$ & Common, widespread \\
\hline 50 & Chironomidae & Midges & $\mathrm{S}, \mathrm{A}, \mathrm{M}$ & $R, S, L, P$ & $\mathrm{O}, \mathrm{H}, \mathrm{C}$ & Common, widespread \\
\hline \multirow[t]{2}{*}{51} & Culicidae & Mosquitoes & $\mathrm{S}, \mathrm{A}, \mathrm{M}$ & $\mathbf{P}$ & $\mathrm{O}, \mathrm{H}$ & Any standing water \\
\hline & Deuterophlebiidae & Mountain Midges & A? & $S$ & $\mathrm{O}, \mathrm{H}$ & Mountain streams \\
\hline \multirow[t]{4}{*}{52} & Dixidae & Dixid Midges & $\mathrm{S}, \mathrm{A}, \mathrm{M}$ & $\mathbf{P}$ & $\mathrm{O}, \mathrm{H}$ & Common, widespread \\
\hline & Ephydridae & Shore Flies & $\mathrm{S}, \mathrm{A} ?, \mathrm{M}$ & $\mathrm{L}$ & $\mathrm{O}, \mathrm{H}$ & Salt Lakes \\
\hline & Psychodidae & Moth Flies & $\mathrm{S}, \mathrm{A}, \mathrm{M}$ & - & $\mathrm{O}, \mathrm{H}$ & Moist areas \\
\hline & Ptychopteridae & Phanton Crane Flies & $\mathrm{S} ?, \mathrm{~A}, \mathrm{M}$ & - & $\mathrm{O}, \mathrm{H}$ & Moist areas \\
\hline \multirow[t]{3}{*}{53} & Rhagionidae & Snipe Flies & A & $\mathrm{R}, \mathrm{S}$ & $\mathrm{O}, \mathrm{H}$ & Genus Atherix \\
\hline & Sciomyzidae & Marsh Flies & $\mathrm{S}, \mathrm{A}, \mathrm{M}$ & - & $\mathrm{C}$ & Prey on snails \\
\hline & Simuliidae & Black Flies & $\mathrm{S}, \mathrm{A}, \mathrm{M}$ & $\mathrm{R}, \mathrm{S}$ & $\mathrm{O}$ & Common filter feeder \\
\hline \multirow[t]{2}{*}{54} & Stratiomyidae & Soldier Flies & S, A,M & $\mathrm{S}$ & $\mathrm{O}$ & Seldom collected \\
\hline & Syrphidae & Flower Flies & $\mathrm{S}, \mathrm{A}, \mathrm{M}$ & $\mathbf{P}$ & $\mathrm{O}$ & Rat-tailed maggots \\
\hline 55 & Tabanidae & Deer and Horse Flies & $\mathrm{S}, \mathrm{A}, \mathrm{M}$ & $\mathbf{P}$ & $\mathrm{O}$ & \\
\hline 56 & Tipulidae & Crane Flies & $\mathrm{S}, \mathrm{A}, \mathrm{M}$ & $\mathrm{R}, \mathrm{S}, \mathrm{L}, \mathrm{P}$ & $\mathrm{O}$ & Common, widespread \\
\hline
\end{tabular}

'S-Saskatchewan

A-Alberta

M-Manitoba

-Absent

"R - Rivers
S-Streams
L-Lakes
P-Ponds

:O-Omnivorous

$\mathrm{H}$-Herbivorous

C-Carnivorous 

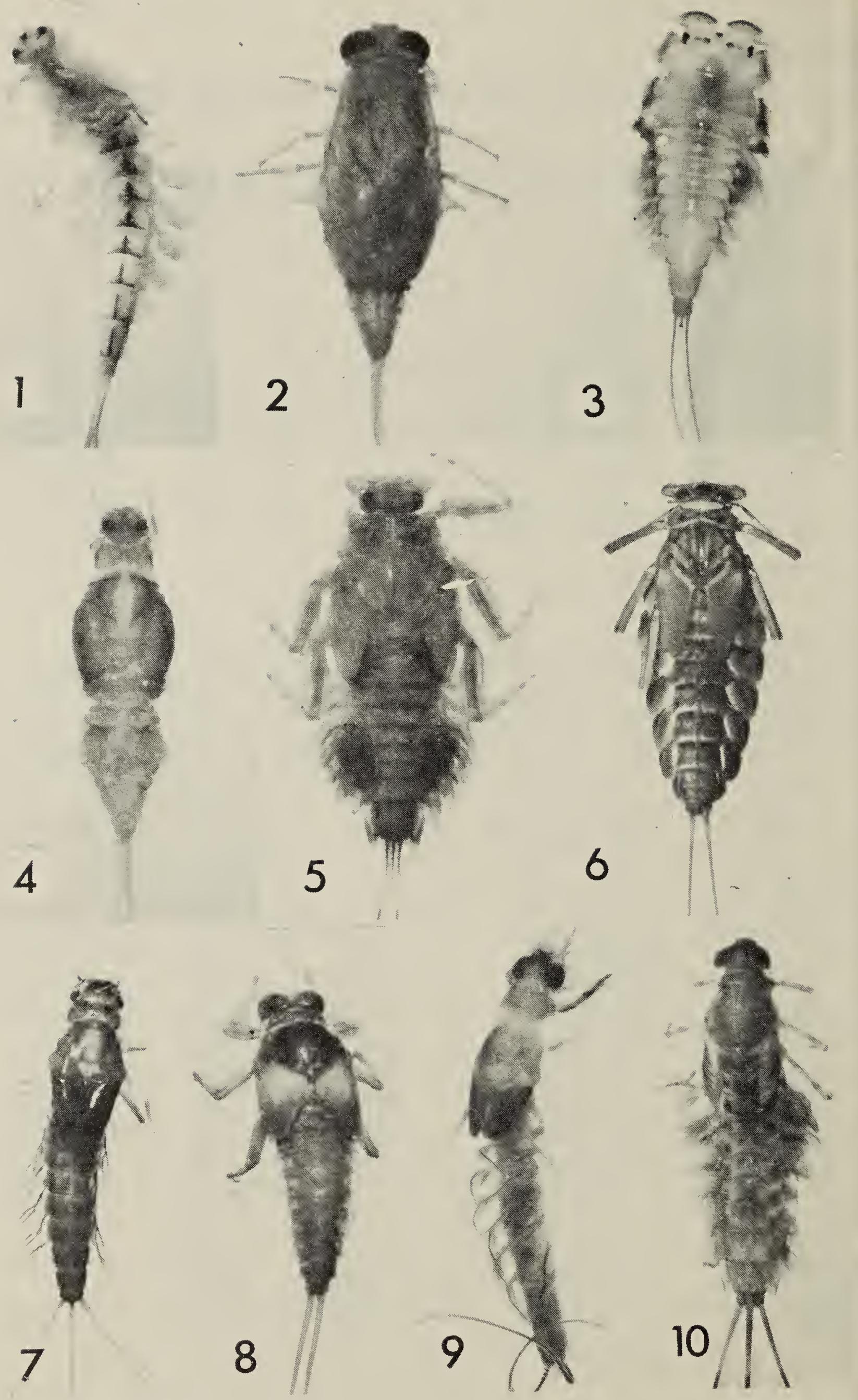

Plate 1. Ephemeroptera

Fig. 1 Ametropodidae: Fig. 2 Baetiscidae: Fig. 3 Behningiidae: Fig. 4 Caenidae; Fig. Ephemerellidae: Fig. 6 Heptageniidae; Fig. 7 Leptophlebiidae; Fig. 8 Oligoneuriida Fig. 9 Polymitarcidae: Fig. 10 Siphlonuridae. 

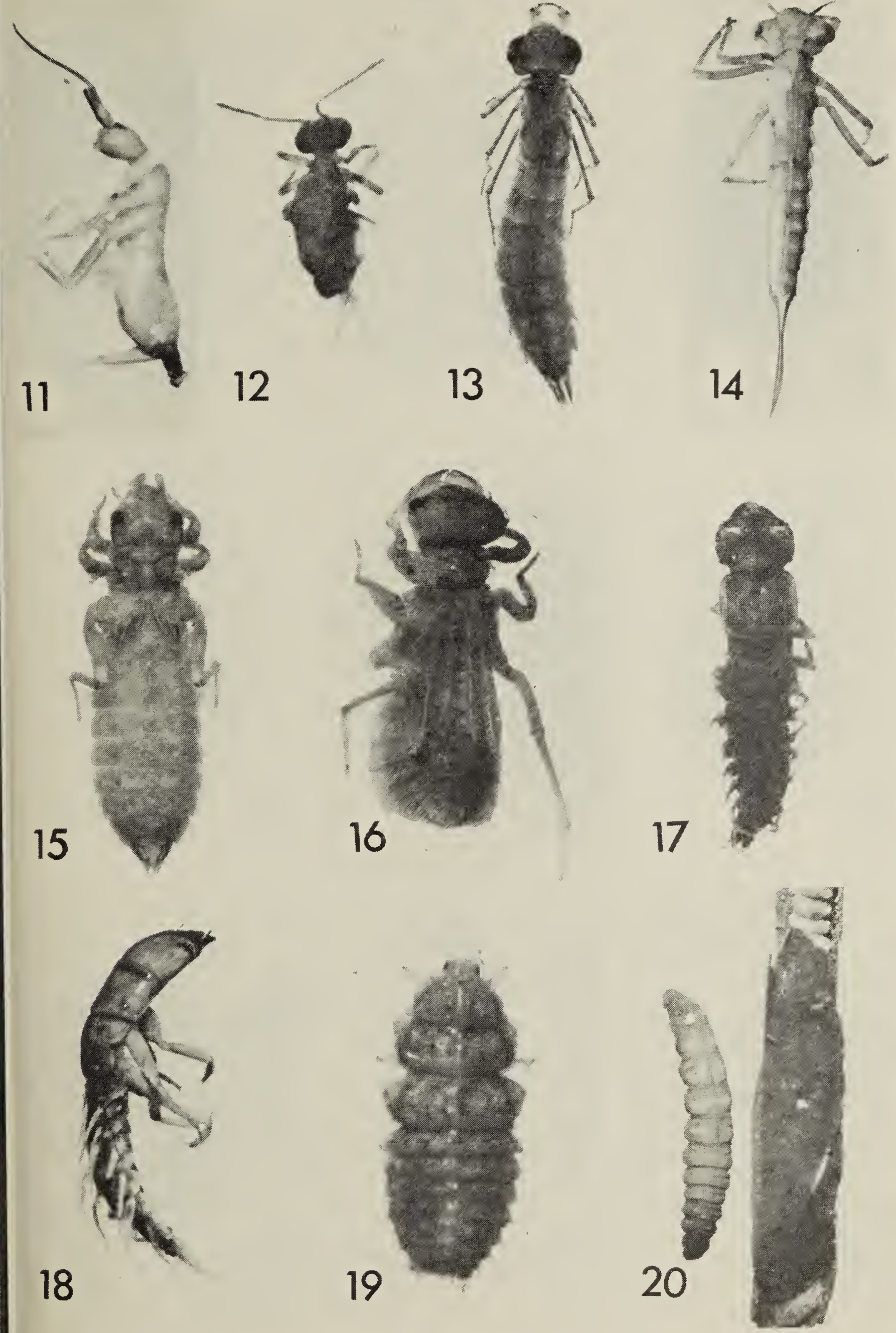

Plate 2. Collembola, Odonata, Megaloptera, Neuroptera and Lepidoptera

Figs. 11 and 12 Collembola: Fig. 13 Aeshnidae; Fig. 14 Coenagrionidae: Fig. 15 Gomphidae: Fig. 16 Libellulidae; Fig. 17 Corydalidae: Fig. 18 Sialidae: Fig. 19 Sisyridae: Fig. 20 Pyralidae. 

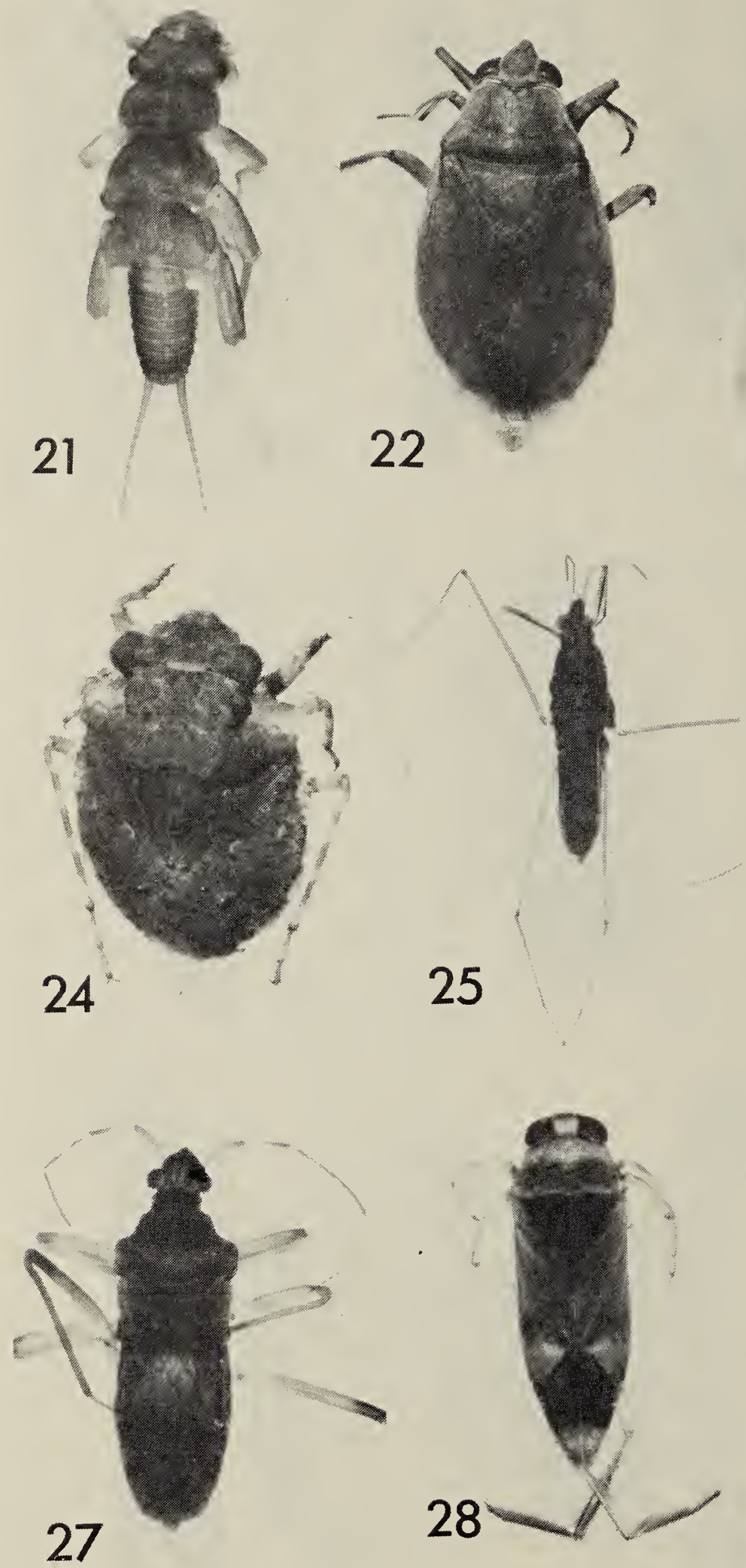
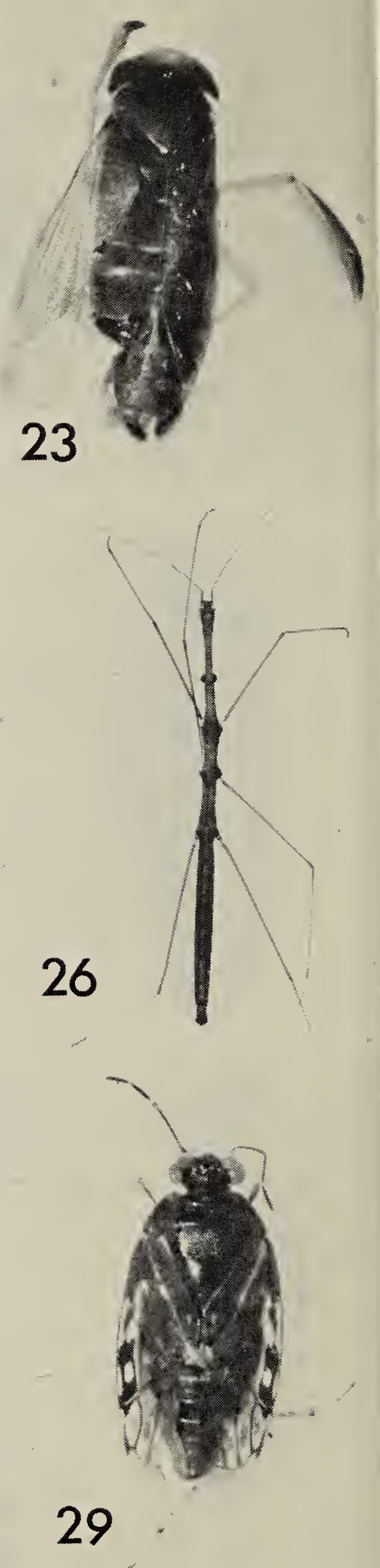

Plate 3. Plecoptera and Hemiptera

Fig. 21 Perlodidae; Fig. 22 Belostomatidae; Fig. 23 Corixidae; Fig. 24 Gelastocorida Fig. 25 Gerridae; Fig. 26 Hydrometridae; Fig. 27 Macroveliidae; Fig. 28 Notone tidae; Fig. 29 Salididae. 

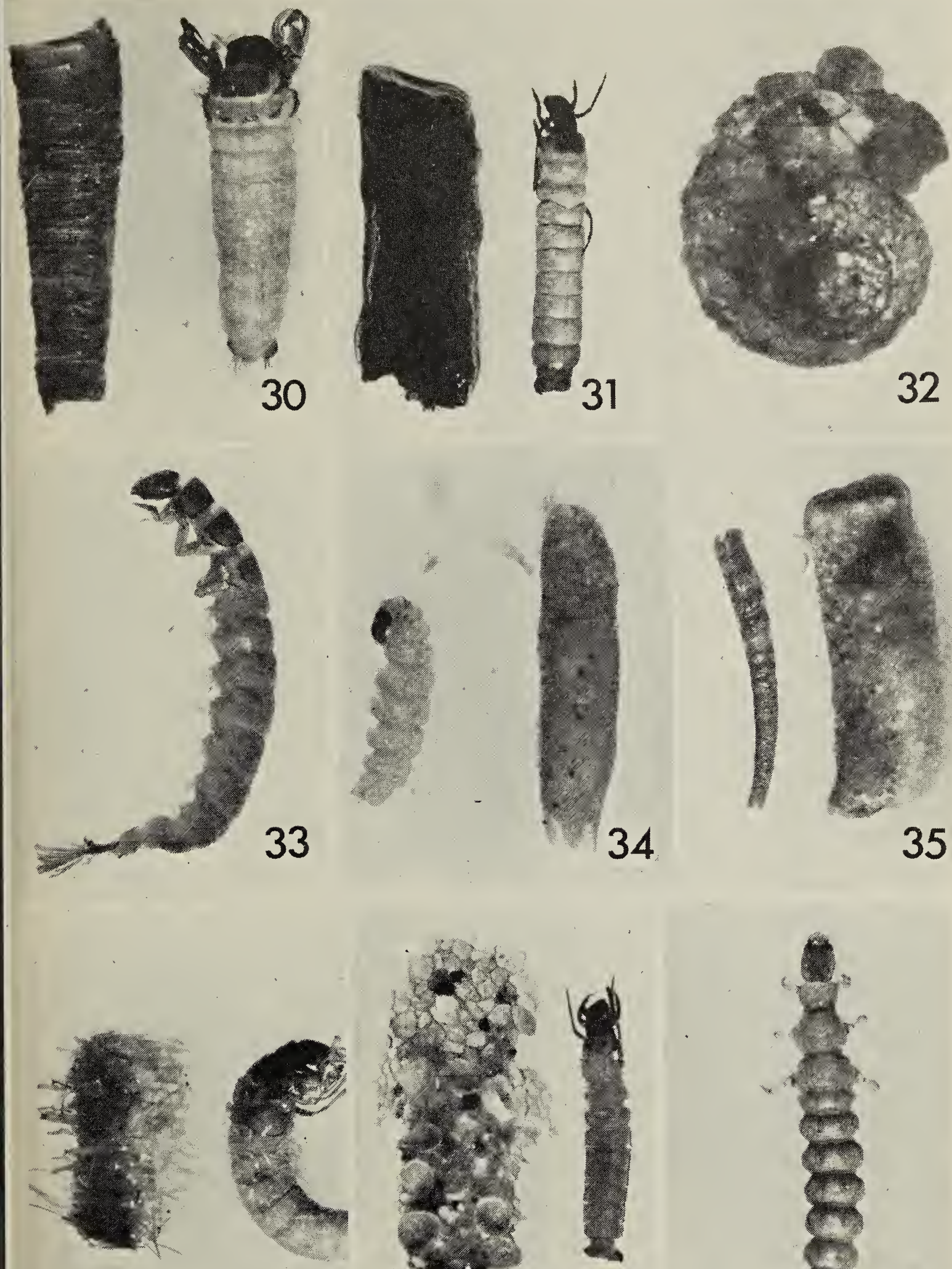

36
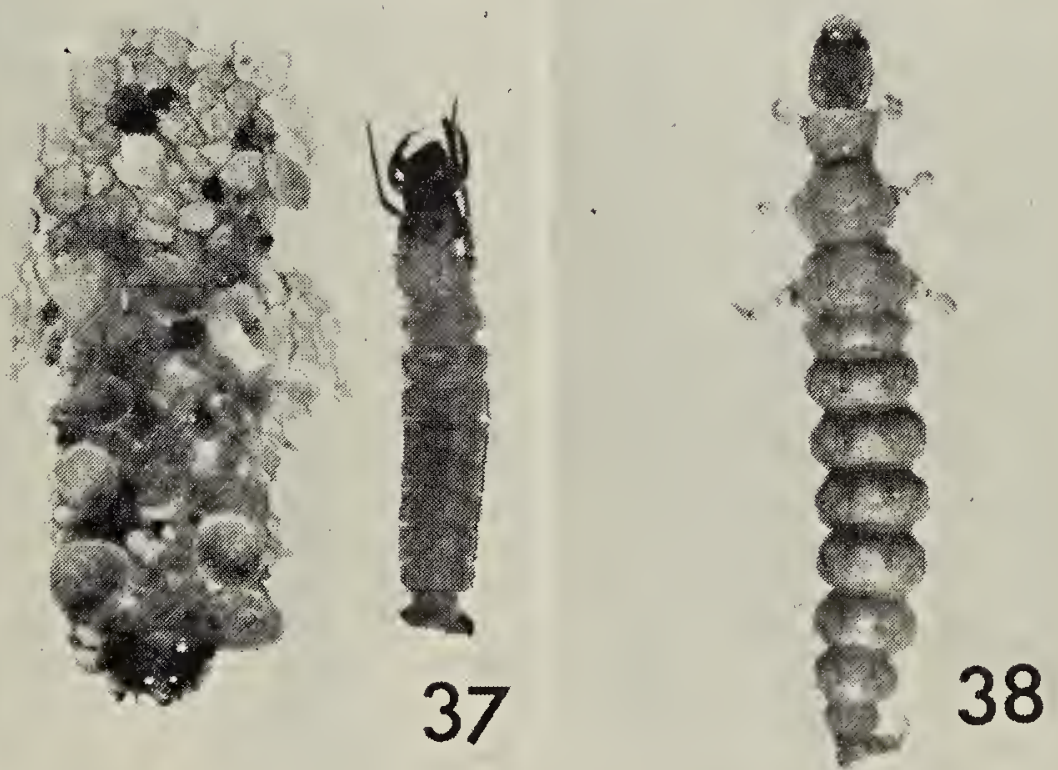

Plate 4. Trichoptera

Fig. 30 Brachycentridae; Fig. 31 Calamoceratidae; Fig. 32 Helecopsychidae; Fig. 33 Hydropsychidae: Fig. 34 Hydroptilidae: Fig. 35 Leptoceridae: Fig. 36 Limnephilidae: Fig. 37 Molannidae: Fig. 38 Rhyacophilidae. 

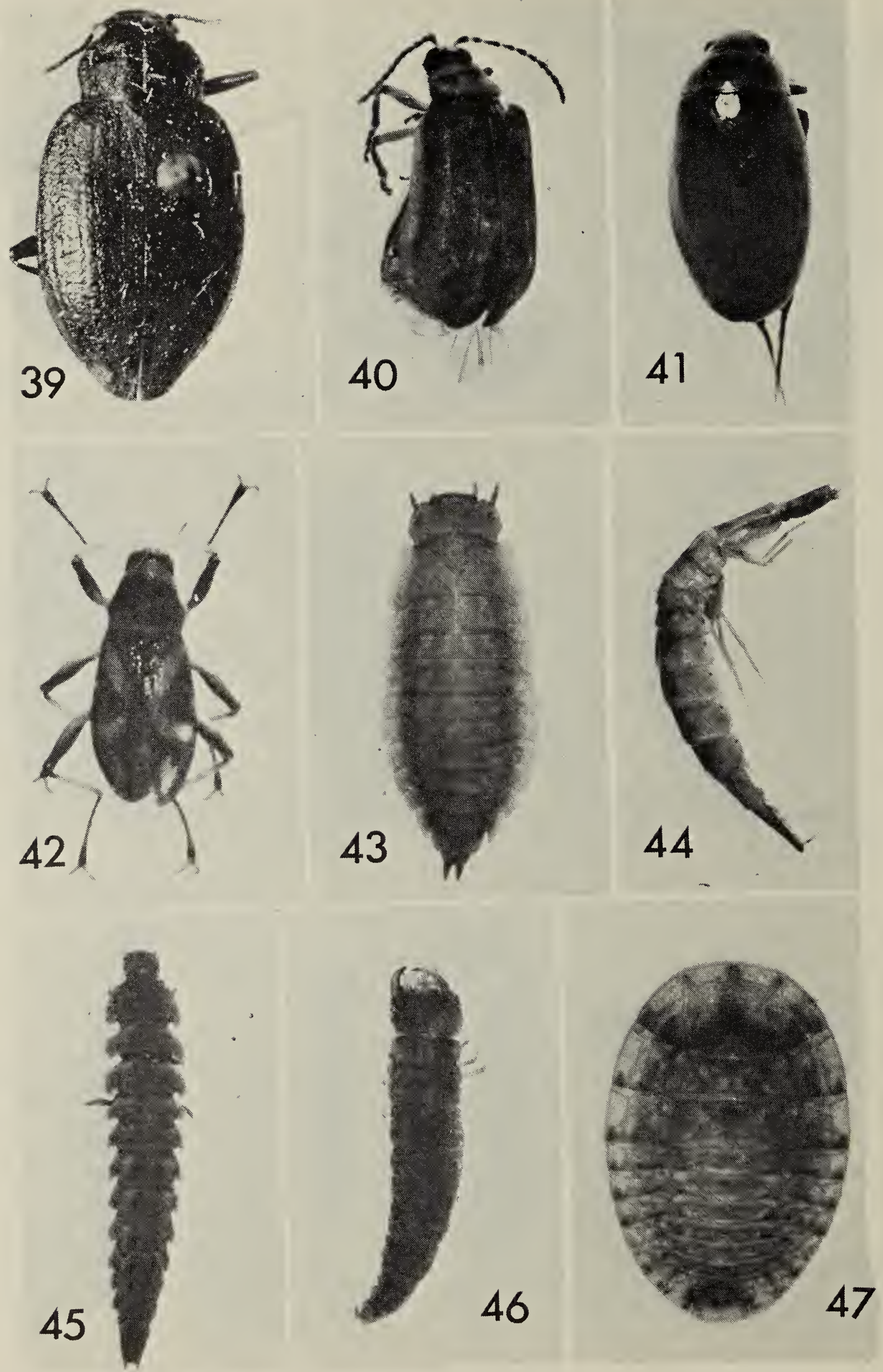

Plate 5. Coleoptera

Fig. 39 Amphizoidae: Fig. 40 Chrysomelidae: Fig. 41 Dytiscidae; Fig. 42 Elmidae: Fig. 43 Amphizoidae; Fig. 44 Dytiscidae: Fig. 45 Elmidae; Fig. 46 Hydrophilidae: Fig. 47 Psephenidae. 


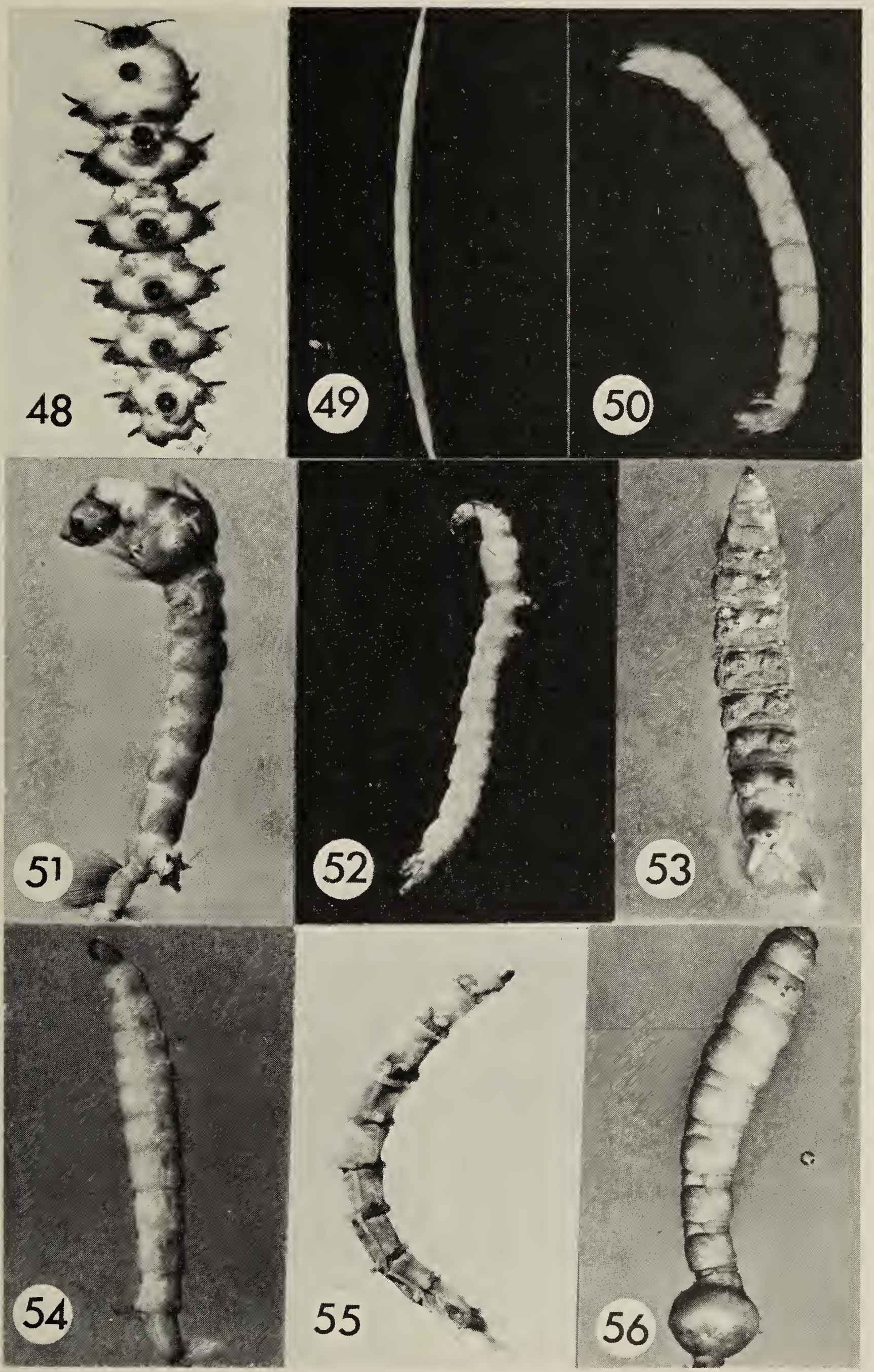

Plate 6. Diptera

Fig. 48 Blephariceridae; Fig. 49 Ceratopogonidae: Fig. 50 Chironomidae: Fig. 51 Culicidae: Fig. 52 Dixidae: Fig. 53 Rhagionidae: Fig. 54 Stratiomyidae; Fig. 55 Tabanidae: Fig. 56 Tipulidae. 